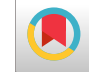

\title{
Repairing Injured Skin: Biologics, Skin Substitutes, and Scaffolds: Review
}

\author{
Hamid Reza Ahmadi Ashtiani ${ }^{1,2,}{ }^{*}$, Melika Akaberi ${ }^{1,2}$, Mohammad Ali Nilforoushzadeh ${ }^{3}$ and Mahdie \\ Farahani ${ }^{1,2}$ \\ ${ }^{1}$ Department of Basic Sciences, Faculty of Pharmacy, Tehran Medical Sciences, Islamic Azad University, Tehran, Iran \\ ${ }^{2}$ Cosmetic, Hygienic and Detergent Sciences and Technology Research Center, Tehran Medical Sciences, Islamic Azad University, Tehran, Iran \\ ${ }^{3}$ Skin and Stem Cell Research Center, Tehran, Iran \\ "Corresponding author: Department of Basic Sciences, Faculty of Pharmacy, Tehran Medical Sciences, Islamic Azad University, Tehran, Iran. Email: ahmadihr@yahoo.com
}

Received 2018 November 07; Revised 2019 January 30; Accepted 2019 February 02.

\begin{abstract}
Context: Skin damage is one of the most common injuries that occur daily for millions around the world. Considering this high prevalence, developing new methods of cells and stem cell administration for healing injured skin is necessary. We discuss different new methods of stem cell and cell administration for repairing injured skin, such as skin stem cell gun, scaffolds, hydrogels, and autologous keratinocytes sheets.

Evidence Acquisition: Many approaches are available in injured skin healing, such as traditional therapy, transplanting, cell therapy, and stem cell therapy. Skin grafting is still a standard solution to treat patients; however, there are a lot of limitations in this procedure, for example, patients with severe burns have an insufficient skin area for grafting, which is a painful procedure.

Results: Although cell therapy approaches dissolve scarring and reduce healing time, considering its high cost, they are not used in everyday society. This article discusses different regenerative dermatology products and compares them with each other.

Conclusions: Herein, we introduced several examples of skin cell products in the pharmaceutics market. Although these products are not well known and even some of them didn't reach clinical trials, comparing different kinds of skin engineered products reveals appropriate guidelines for their use and entrance to dermatology market.
\end{abstract}

Keywords: Cell Therapy, Wound Healing, Stem Cell Gun, Scaffold, Hydrogel, Autologous Keratinocytes Sheet

\section{Context}

Skin is an essential organ in the first line of a defense system. It is formed of two layers: outer epidermis and inner dermis; each layer has specific functions, such as prevention of dehydration, a barrier to avoid trauma, vitamin D synthesis, and immune control (1). Wound healing and thereby repairing of the skin tissue is a very complicated process and depends on several factors, such as wound type, tissue damage by burning: first, second, and third degree, or physical trauma, inflammation, and secondary infections (2). As a healing process, the first step is to avoid excessive blood loss and prevent microbial infection. More importantly, it is necessary to restore the function of the damaged tissue or cell through healing (2).

Wound treatment is an essential part of the health care system. The treatment of wounds and associated complications have expensive costs. Chronic and non-healing wounds are especially costly since they require repetitive treatments $(3,4)$.
Cell therapy is the transplantation of autologous or allogeneic cells through local or systemic routes of administration to restore the ability or function of damaged tissues. Stem cells are the best selection for cell therapy due to their potential for self-renewal, differentiation, and elasticity (5).

Due to its enormous size and ease of accessibility, the skin is a natural target for stem cell research. Subcutaneous tissue has the capacity for multi-potential differentiation. Although skin grafting is still commonly used to treat patients with cutaneous wounds, there are some limitations and deficiencies associated with these standard procedures. For instance, in patients with severe burns, there are insufficient skin areas to be harvested for skin grafting and the patient can be in critical conditions secondary to sepsis or fluid loss (6). Moreover, skin grafting is a painful procedure and creates an additional wound at the donor site. The transplanted skin is unable to grow with the patient and can cause restricted joint movement.

Copyright (c) 2019, Journal of Skin and Stem Cell. This is an open-access article distributed under the terms of the Creative Commons Attribution-NonCommercial 4.0 International License (http://creativecommons.org/licenses/by-nc/4.0/) which permits copy and redistribute the material just in noncommercial usages, provided the original work is properly cited. 
Stem cell and cell therapy dissolves scarring and significantly reduces healing time (7).

In this review, we discuss different methods of stem cell and cell administration for repairing injured skin.

\section{Evidence Acquisition}

In order to design a suitable regenerative skin product, we should have a brief view of its components. Different kind of cells and their route of administration is discussed here.

\section{Different Type of Cells in Skin Repair and Regenera- tion}

\subsection{Pluripotent Stem Cells}

The Pluripotent stem cell is the most powerful type of stem cell.

They are essential due to their self-renewal and differentiation into any of the three germ layers, ectoderm, endoderm, and mesoderm. These three germ layers can differentiate to make all human organs and tissues.

There are several types of pluripotent stem cells.

Embryonic stem cells are the best example of natural pluripotent stem cells. In addition, a type of human-made pluripotent stem cell also exists, which is called an induced pluripotent stem cell (IPS) (8). IPS cells were first produced from mice cells in 2006 and human cells in 2007; they are functionally similar to embryonic stem cells.

They can differentiate in an extended diversity of tissues and their non-controversial nature; pluripotent stem cells are well-suited for use in cellular therapy and regenerative medicine. iPSCs are used in personalized drug discovery efforts and understanding the patient-specific basis of disease (9).

\subsection{Fetal Cells}

These cells are derived from the fetal tissue, such as fetal bone marrow, blood, kidney, and liver. As their name was proposed, fetal cells derived from the fetus. The growing baby is considered a fetus from almost 10 weeks of pregnancy. Most fetus tissues include pluripotent stem cells, which cause the progress and rapid growth of the organs. Fetal blood is an excellent source of hematopoietic stem cells that generate blood cells faster than those in adult bone marrow or cord blood. These stem cells, as adult cells, are commonly tissue-specific and create the mature cell type in the specific organ or tissue which they exist. Fetal cell classification stands doubtful (10). Fetal fibroblasts and keratinocytes are valuable sources in skin regenerative medicine as they have the pattern of scarless wound healing.

\subsection{Mesenchymal Stem Cell}

The cells that derived from the stroma, the connective tissue that enclosed other organs and tissues, have occasionally been referred to as a mesenchymal stem cell or MSC. Many scientists correctly named them as stromal cells. The first MSCs were detected in bone marrow and showed the ability to create bone, chondrocytes, myocytes and adipocytes, umbilical cord, and dental pulp (11); as long as the mesenchymal stem cell has been developed from other tissues, such as cord blood and adipose. Varied MSCs are imagined to have stem cell; in addition, the ability of immune modulatory are being examined as a cure for various disorders; however, there are a few documents that are useful. Scientists do not have enough information regarding the type of cells that they can produce; these cells, in reality, are the stem cell. While they do concur that all MSCs are not the same, their properties depend on how they are derived, enlarged, and also the part of the body that they belonged to (12).

\subsection{Umbilical Cord Blood Stem Cell}

The blood of the umbilical cord gathered at birth is an excellent source of stem cells, which can be utilized in the clinic and research to cure the disease of the immune system and blood. Right after birth, with the consent of parents, the blood of the umbilical cord of newborn baby can be gathered. The transplantation of umbilical cord blood is highly used for various benign and malignant hematological diseases and other complications (13). Umbilical cord blood mesenchymal stem cells are the most potent stem cells that can be used in allografts due to their low immunogenicity.

\subsection{Keratinocytes}

Keratinocytes reside in the epithelial layer of the skin. They are differentiated epidermal stem cells that move upwards in the epidermis and produce proteins such as keratin, which are critical to the integrity of the outer layer of the skin (2). Keratin has two main functions: forms a protective layer on the outside of the skin and adheres cells to each other. Keratinocytes have critical roles in the wound healing process. They increase fibroblast proliferation, however, by secreting mmp1, abnormal collagen bundles will be reduced, and a normal re-epithelialization occurs.

\subsection{Fibroblast}

Fibroblasts are the most abundant cells in the dermis, which play a critical role in wound healing. Fibroblasts involve in critical processes such as creating extracellular 
matrix, collagen, elastin, and breaking down the fibrin clot (14).

Fibroblasts appear in the wound area after two or three days. Fibroblasts exert traction force like a treadmill on the collagen fibrils in the extracellular matrix, which rearrange and compact the size of injured skin (2).

\section{Routes of Stem Cells Administration to the Skin}

\subsection{Spraying Cells}

\subsubsection{Skin Stem Cell Gun}

History: An exciting discovery arose for burn victims. In 2008 the skin cell gun was developed. Joerg C. Gerlach, at the Department of Surgery at the University of Pittsburgh's McGowan Institute for Regenerative Medicine, developed a new method to treat burn victims by harvesting the patients healthy, undamaged skin cells, and spraying them on the damaged burn site using a skin stem cell gun (15, 16).

Methods of Application: The skin cell gun works like a complicated paint gun. The gun uses an electronically pneumatic system that does not injure the skin cells (3). When a patient has second-degree burns, they take a biopsy from the patient's healthy cells. The healthy cells in the biopsy isolated and sprayed an aqueous solution of the skin cells onto the damaged skin. The new layer of skin is covered with new dressings that have tubes that run through end to end. One acts as an artery and the other acts as a vein; then, they are connected to an artificial vascular system. The new cover keeps the wound sterile and arranges electrolytes, amino acids, glucose, and antibiotics to the wound (17).

Advantages:

- Drastically cuts healing time (16).

- The patient is less likely to get an infection, unlike scaffolds that will increase the risk of infection.

- Painless (16).

- Quick (16).

- Regenerated skin looks very natural $(16,18)$.

- Skin cells will grow into fully functional cells (dermis, epidermis, and blood vessels).

- Minimal scarring $(16,17)$.

Disadvantages:

- This method is limited to second-degree burns for now (15).

- In 2011, only several dozen patients were treated with this treatment, and it is still experimental (15).

- Was only successful immediately after the burn or within the first week (15).

\subsection{Scaffold}

\subsubsection{Scaffold (Artificial Skin)}

History: During the 1970s, the first artificial skin was developed by Burke and Yannas. Burke, treated many burn victims that felt the need for artificial skin. Today's methods for cure burn victims are effective; however, many patients continue to die since their bodies are unable to make enough healthy skin to heal the injured area, or due to the fact that they reject the received graft skin. After years of research, they finally developed a polymer that is suitable for an artificial skin (19-21).

Methods of Application: Yannas-Burke team called the artificial skin Silastic. Silastic is a bi-layer polymer with repeating molecular structures. It can be natural or synthetic. The artificial skin had two layers of polymers, one of the layers is synthetic, and the other is organic. The top layer of Silastic protected the skin from infection and dehydration and composed of a thin silicone sheet. The bottom layer of Silastic acted as a seedbed for healthy skin cells taken from the victim's body; it was a kind of scaffolding made from the material in cow tendons and shark cartilage. To use Silastic, a doctor would place the film over the burned skin of the victims (19-21).

Advantages:

- It looks real.

- It can help people lead normal lives that have had severe skin trauma $(21,22)$.

- This method can be used several weeks after injury, unlike the stem cells gun.

Disadvantages:

- It can be quite expensive.

- Your skin may develop allergies to artificial materials $(21,22)$.

Many products had been produced with this method, which will be discussed in the following:

- Dermagraft

- TransCyte

- AlloDerm

- Integra (23).

\subsection{Hydrogels}

\subsubsection{Hydrogel}

History: Hydrogels are cross-linked polymers network, which is made of up to $90 \%$ water. These polymers were developed in the 1960s; however, they were earlier discovered by du Pont (du Pont de Nemours, 1936) (24).

Methods of Application: Hydrogels are applied onto or into injured areas and are covered with a secondary dressing such as film or foam. Hydrogels can remain in the area for up to three days. Hydrogels are used in dry, sloughy wounds, as well as partial thickness wounds (25). 


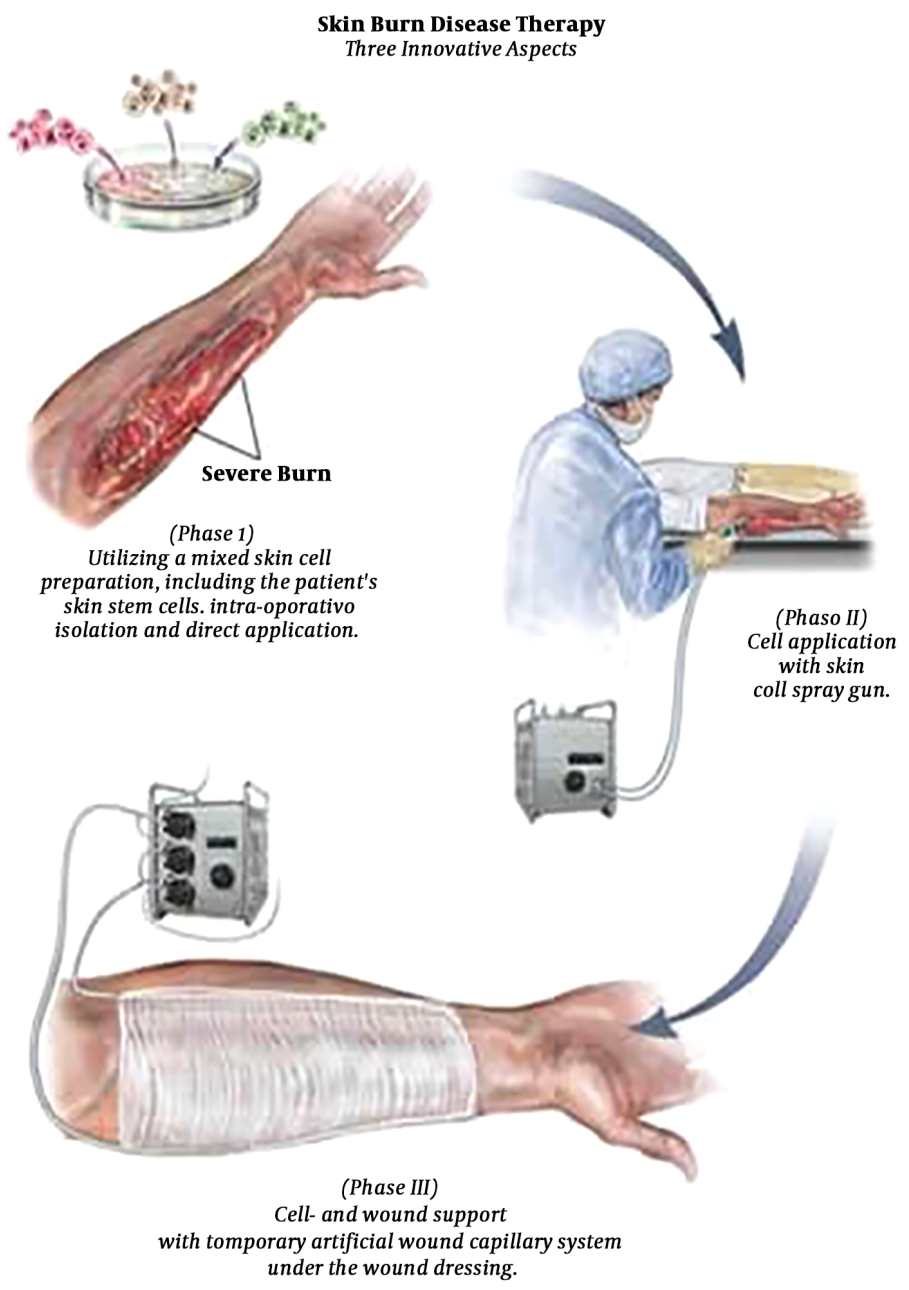

Figure 1. Method of using skin cell gun

Hydrogel sheets do not conform well to the area of the hands; however, they will conform to the arm area. Gels and impregnated gauze can easily be kept in place on the hand with a secondary dressing. Hydrogels are usually replaced every 24 to 72 hours, however, depending on how much exudates, if any is being secreted by the wound (26).

Advantages:

- Exhibited better dermal matrix deposition (27).

- Less wound contraction (27).

- Treat large surface area burns (27).

- Act fast to help cool down a wound (26).

- Candidate for tissue engineering (28).

- Hydrogels are useful for dry wounds to mildly exude (29).
- Ability to easy incorporate antimicrobial agents for controlled release (24).

- Reduced scarring unlike scaffold (30).

Disadvantages:

- Not recommended for heavily exuding wounds (31).

- Require a secondary dressing (31).

- May dry out and adhere to wound bed (31).

- May macerate surrounding skin (31).

Many products had been produced this way we discuss these products:

(1) P-DERM ${ }^{\circledR}$

(2) DuoDERM ${ }^{\circledR}$

(3) Skin-on-Skin Hydrogel Pads ${ }^{\circledR}$ 


\subsection{Keratinocytes Sheet}

\subsubsection{Autologous Keratinocytes Sheet}

History: Cultured keratinocytes have been used for 20 years to treat burns and other cutaneous wounds (32). In 1975, Rheinwald and Green described a method of culturing human epidermal cells and cultured epidermal sheet autografts to complement autologous split-thickness skin grafts to treat severe burns or other large wounds (33).

Methods of Application: By using different techniques, human primary keratinocytes were transplanted in vitro in a standard manner. Keratinocytes were counted before and after transplantation, on days four, eight, and 14 by vital staining. Cell survival varied, ranging from $47 \%$ to $>$ $90 \%$, depending on the method. However, the proliferation assays showed that the differences in numbers diminished after eight days of culture (34).

Well-dispersed cell suspension was aspirated into one $\mathrm{mL}$ syringes, and then the cells were sprayed into individual $100 \mathrm{~mm}$ Petri dishes from a distance of $10 \mathrm{~cm}$. 1 drop of the cell suspension was dropped on to the surface, aiming for an even distribution of the cells and using as much pressure as needed to obtain a steady flow or drip of suspension (34).

Advantages:

- The reduced time required for culture (34).

- In suspension can be easily transported from the laboratory to the patient in small vials (35).

- Vast expansion from the small donor site (36).

- Use of allografts as biologically active dressings (36).

- Low risk of viral disease transmission (36).

Disadvantages:

- Use of potentially immunogenic materials in graft production (36).

- Widely varying graft take (36).

- Wound contraction (36).

- Time-consuming Preparation of the grafts (36).

- Expensive (37).

- They are hard to handle the cause of their 8 - 10 cells thickness (37).

Many products had been produced this way, and we want to discuss these products:

- Epicel ${ }^{\circledR}$

- Epidex ${ }^{\circledR}$

- My skin ${ }^{\circledR}$

\section{Results}

Appropriate combination of different routes of administration and desired cells results in emerging skin products that are briefly discussed and compared with each other in this article.

\subsection{Dermagraft ${ }^{\circledR}$}

Company: Dremagraft, which is produced by Organogenesis Inc., Canton, MA, USA is sterile and derived from human dermal fibroblasts generated by the culture of neonatal dermal fibroblasts onto a polyglactin mesh scaffold (3840).

This product was FDA approved for the treatment of diabetic foot ulcers (DFU). This treatment has been proven safe and effective in a large and randomized clinical trial (41).

History: Shire Regenerative Medicine, Inc. San Diego, CA, USA (2001).

Company: Dermagraft is currently in a clinical trial, and it is being developed to cure Venous leg ulceration (VLU). They compared Dermagraft in conjunction with four-layer compression bandaging therapy versus fourlayer compression bandaging therapy alone (40).

Methods of Producing: During the manufacturing process, the human fibroblasts lead to fill the scaffold and secrete collagen, some extracellular matrix proteins, cytokines, and growth factors, creating a three-layer humanderived dermal substitute containing metabolically active cells. Dermagraft contains human dermal fibroblasts and their secreted products. The polyglactin mesh has been tested and approved for use in humans and is commonly used as suture material $(38,39)$.

Application:

- Clean the ulcer with a sterile saline solution. This is to make sure their surface for application of Dermagraft is clean (41).

- Dermagraft will be thawed and cut to the size of your ulcer (41).

- Placed Dermagraft on your ulcer and cover it with another dressing to keep it protected (41).

- There is instruction on how to use, how to care the ulcer, how to change the dressing, and how to keep pressure off the ulcer (41).

Advantages:

- Compared to the allograft it is easier to remove and have higher patient satisfaction (42).

- Better than allograft for graft take, wound healing time, and infection (43).

- No adverse effect and no evidence of rejection (43).

Disadvantages:

- Used for temporary coverage (42).

- Six-month shelf life (42).

- It causes pain, unlike the stem cell gun.

5.2. TransCyte ${ }^{\circledR}\left(\right.$ TranCyte $\left.^{\circledR}\right)$

Company: TranCyte, which is produced by Shire Regenerative Medicine, Inc. San Diego, CA, USA; Smith \& Nephew, 
Inc., Largo, FL, USA (1997), is human allogeneic fibroblast from neonatal foreskin seeded onto silicone covered bioabsorbable nylon mesh scaffold, secreting components of the extracellular matrix, and many local growth factors (44). Temporary dressing deep partial thickness and full thickness burn wounds like chronic leg ulcers as well as diabetic foot ulcers lasting more than six weeks (45).

History: Advanced Tissue Sciences, developed Dermagraft and TransCyte, a company founded in 1987. TransCyte received a pre-market approval (PMA) from the FDA for the treatment of certain types of burns in 1997 (46).

Methods of Producing: Fibroblasts are seeded onto a nylon mesh. They lead to produce human dermal collagen, matrix proteins, and growth factors. No cellular metabolic activity remains by freezing; however, the tissue matrix and bound growth factors are left intact (47).

Application:

- TransCyte was applied at the patient's injured area using adhesive strips. TransCyte may be stapled in place (47).

- Thoroughly cover the wound bed with TransCyte, up to and including the edges of non-burned skin.

- Avoid contact with moist burn creams or treatments (47).

- For multiple piece application, overlap each piece approximately $1 / 2$ inch $(1.3 \mathrm{~cm})(47)$.

- Wrap a dry, non-adherent dressing over TransCyte after it has been secured. The dressing should be wrapped snugly over the TransCyte (47).

- After 24 hours, remove the dressing and observe TransCyte (47).

- Monitor wound routinely and intervene if fluid or exudate appears under the TransCyte. Fluid may be removed by cutting a slit in the TransCyte by using a syringe to aspirate or by windowing (47).

- When TransCyte is adherent, the dry bandage is removed, and TransCyte left open to air (47).

Advantages:

- Compared to the allograft it is easier to remove (48).

- Used for partial thickness burns; however, the stem cell gun is only used for second-degree burns.

- Improved healing rate.

-1.5-year shelf life that is more than Dermagraft (48).

Disadvantages:

- Expensive (48).

\subsection{AlloDerm ${ }^{\circledR}$}

Company: LifeCell Corporation Branchburg, NJ, USA (1992).

Skin substitute Living Cell Therapy Human skin allograft derived from the donated human cadaver (49).

FDA approval for Burns and full thickness wounds (50).
History: AlloDerm was the first product for sale, and the company grew very fast. AlloDerm was developed in 1994 by the biotechnology company LifeCell. LifeCell experienced a 55\% overall revenue growth between 2003 and 2004, and the trend has continued in more recent years, despite the company's voluntary recalls of their product due to the controversy surrounding their tissue collection methods (51).

Methods of Producing: Cutting sheets of dry acellular tissue matrix into strips, at cryogenic temperatures, cryofracture the dry acellular tissue matrix, separating the particles by size at cryogenic temperatures; freeze drying the fraction of particles desired size to remove any moisture that may have been absorbed to give a dry particulate acellular tissue matrix, and rehydrating the dry tissue matrix (52).

Application:

- Open and remove the foil pouch (53).

- Remove the plastic holder with the aseptic technique. The plastic holder is sterile and placed directly into the sterile field (53).

- Aseptically remove the tissue. Always use sterile gloved hands when handling AlloDerm (53).

- Soak the tissue for a minimum of two minutes. Use a sterile basin, and room temperature sterile saline or room temperature sterile lactated Ringer's solution to cover the tissue (53).

- Until ready for implantation store the tissue in the room temperature sterile solution. The tissue can be stored in a sterile solution for a maximum of four hours (53).

- AlloDerm has two layers, a basement membrane, and a dermal surface. When applied as an implant, it is recommended that the dermal side is placed against the most vascular tissue (53).

- If any hair is visible, remove before implantation (53).

- AlloDerm should be hydrated and open the package. Do not use when AlloDerm is dry (53).

- AlloDerm is limited to use by specific health professionals (e.g., physicians, dentists, and/or podiatrists) (53).

Advantages:

- Immediate useful wound coverage (48).

- Can vascularize over exposed bone and tendon (48).

- Allows grafting of ultra-thin STSG as one-stage procedure (48).

- Immunologically inert since the cells responsible for immune response and graft rejection are removed during the processing (48).

- Reduced scarring (48).

- The injectable micronized form is also available (Cymetra $\left.^{\circledR}\right)(48)$. 
- Two-year shelf life, which is more than Dermagraft and TransCyte.

Disadvantages:

- Risk of transmission of infectious diseases, although no cases of viral transmission have been reported, unlike stem cell gun that causes no infection.

- No viral or prion screening (48).

- Collection fluid risk (48).

- The possibility of donor rejection (48).

- Requires two procedures that are more difficult than Dermagraft and TransCyte.

- Expensive (48).

- Inability to replace both dermal and epidermal components simultaneously (48).

\subsection{Integra ${ }^{\circledR}$}

Company: Integra, which is produced by LifeSciences Corporation, Plainsboro, NJ, USA (1996), is a bovine collagen type I and shark chondroitin-6-sulfate annexed to silicone membrane. FDA approval for pressure ulcers, diabetic ulcers, venous ulcers, chronic vascular ulcers, surgical wounds, trauma wounds, and draining wounds (48).

History: In 1996, the FDA approved the first product of the company, Integra ${ }^{\circledR}$ dermal regeneration template, a collagen matrix designed as a skin replacement for the treatment of third-degree burn victims. Integra ${ }^{\circledR}$ dermal regeneration template was the first product approved with a claim of regeneration of dermal tissue (54).

Methods of Producing: Integra ${ }^{\circledR}$, available in meshed and non-meshed form (Integra ${ }^{\circledR}$ template), is a bi-layer membrane system for skin replacement. The dermal replacement layer is made of a porous matrix of fibers of bovine tendon collagen and glycosaminoglycan that is produced with controlled porosity and defined degradation rate. The epidermal layer is made of a thin silicone layer to control moisture loss from the wound (54).

Application:

- The wound is cleaned, and the damaged tissue or contracture scar is completely removed to viable tissue in preparation for the application of the Integra ${ }^{\circledR}(54)$.

- Integra ${ }^{\circledR}$ Template is applied to the removed wound bed. Fluids invade the matrix within minutes of application, adhering it to the wound (54).

- Dermal cells begin migrating into the matrix and establish a new vascular network (54).

- Collagen (protein) in the Integra ${ }^{\circledR}$ template is replaced by collagen organically produced by new dermal skin cells (54).

- Upon formation of a new dermal layer, the Integra silicone layer is removed. The Integra collagen template biodegrades and is absorbed into the body, leaving new dermal skin (54).
- A thin 0.004 - 0.006 in. (0.1016 - $0.1524 \mathrm{~mm}$ ) epidermal autograft is applied over the new dermal skin (54).

- Successful engraftment completes the procedure yielding a permanent and lasting wound closure (54).

Advantages:

- Median take of $85 \%$ (36).

- One of the most accepted artificial skin substitutes (55).

- More aesthetic compared to autograft.

- A two-stage procedure requires a minimum of three weeks between the application of Integra ${ }^{\circledR}$ and STSG (55).

- Safe and effective for burn reconstruction.

- Integra Wound Matrix ${ }^{\circledR}$ approved through the $510(\mathrm{k})$ process in $2007(56,57)$.

Disadvantages:

- High risk of infection and graft loss since it is avascular, unlike the stem cell gun that causes no infection (58).

- Complete wound excision (58).

- It causes scarring, unlike the Hydrogel and stem cell gun that causes no scars.

\subsection{P-DERM ${ }^{\circledR}$}

History: P-DERM, which is produced by polymer science is a custom coated material for the electronics industry and medical device worldwide. ISO 13485 and polymer science is ISO 9001 and registered with the FDA (59).

Methods of Using: P-DERM ${ }^{\circledR}$ hydrogels have hydrophilic polymer matrix and high water, which helps control fluid exchange from a wound's area. All of the hydrogels are manufactured in the USA and display good cooling and adhesion properties (59).

Application:

- Device fixation: In the first step, fix the hydrogel onto the injured area (59).

- Transdermal drug delivery: After two weeks drug delivers into damage cells and skin (59).

- Burn care (59).

- Advanced wound care (59).

- Blister care (59).

Advantages:

- Good converting properties (59).

- Compatible with multiple (59).

- Methods of sterilization are easy (59).

- Lower minimum order quantity (59).

- Excellent instantaneous tack (59).

- Reliable stability (59).

- Customization of width to minimize waste (59). 


\subsection{DuoDERM ${ }^{\circledR}$}

DuoDERM $^{\circledR}$ is a sterile gel, which is clear, preservativefree, and a viscous hydrogel that incorporates a unique ConvaTec hydrocolloid formulation that separates it from other hydrocolloid dressings. It is useful for partial and full-thickness wounds as well as a filler for dry cavity wounds to provide moisture for dry wounds (60).

Company: ConvaTec is a global medical and technologies company that is focused on therapies for the chronic conditions, with leading market positions in advanced wound care, continence, critical care, and infusion devices (60).

Methods of Producing: Hydrocolloid dressings are described as powders, wafers, or pastes composed of materials such as pectin, gelatin, and carboxymethyl cellulose. They provide a moist environment favorable for wound healing and a barrier against exogenous bacteria. (61).

Application: (61).

- Wash hands then dry the surrounding damage area

- To select the appropriate dressing size measure the wound, allowing a $3.0 \mathrm{~cm}$ overlap on the intact skin around the whole wound (61).

- Warm the dressing between your hands (61).

- Remove the top white release paper, being careful to minimize finger contact with the adhesive surface (61).

- Hold the adhesive side over the wound (61).

- Align the dressing with the center of the wound (61).

- Apply the center part of the dressing (61).

- Remove the bottom white release paper while rolling the dressing in place but do not stretch it (61).

- Repeat the above procedure on the other side and remove the clear release paper (61).

- Gently mold the dressing into place for 30 - 60 seconds (61).

- Lift one corner of the dressing (61).

- Roll it away from the wound while holding the skin away (61).

- Gently lift the corners and pull upwards until the dressing completely peels off(61).

Advantages:

- Easy to use and are suitable for different stages of wound healing and multiple wound types (61).

- Reduce the risk of further skin breakdown due to friction (61).

- It is effective in the treatment of small partial thickness burns and is especially useful in the healing of minor burns (61).

Disadvantages:

- They may initially increase the wound size (62).

\subsection{Skin on Skin Hydrogel Pads ${ }^{\circledR}$}

Hydrogel Skin Pads combines gel with a support mesh and vitamin E to help provide protection against blisters, rubbing, and rips. This combination cools and soothes as well as irritated and damaged the skin. This combination includes 200 hydro gel skin pads (63).

Company: Medi-Dyne Healthcare Products is a global company dedicated to providing innovations in preventive health care. Medi-Dyne's contributions have over 60 patented foot care, knee, stretching, and strengthening innovations.

Methods of Using: Hydrogels are permeable to water vapors, gases, and small protein molecules; however, it is the barrier for bacteria. The research has shown that the cooling element of the dressing provides a moist environment at the surface of the wound reduces pain in the wound. The reduction of pain has a direct impact on improving the quality of life (63).

Application:

- Remove the film and apply the hydrogel side of the pad to the desired area (63).

- Keep unused portions of skin-on-skin pads inside a sealed bag to prevent drying (63).

- Skin-on-Skin non-sterile hydrogel pads should not be used on open wounds. Please consult the physician immediately, if open wounds, chronic skin problems, or if infection occurs (63).

Advantages:

- Effective under compression therapy (64).

- By cooling tissue wound, pain is reduced and bathing nerve endings (64).

- Pain is managed throughout wear time not just at dressing change (64).

- Removing devitalized tissue by donating moisture to dry wounds and absorbing exudate from wet wounds (64).

- Gentle even on the most fragile skin (64).

Disadvantages:

- Should not use on open wounds, unlike scaffold and stem cell gun.

- See your physician or medical professional for these conditions, continued irritation, or injuries that may be a result of diabetes (65).

\subsection{Epicel $^{\circledR}$}

Company: Epicel produced by Genzyme Corp, Cambridge, MA, USA.

Patients who have deep dermal or full thickness burns comprising a total body surface area greater than or equal to $30 \%$ can use cultured epidermal autografts. Cultured epidermal autografts, may be useful in severity and extent burns (37). 
History: Junggren, in 1898, succeeded in keeping skin for long periods for the first time then transplanting them back into the area. Karasek (1968) performed transplants of autologous keratinocytes from primary cultures in rabbits. He proved that these cultures are useful and rise to an epidermis (66).

In the 1980s, scientists already developed methods to produce in vitro human keratinocyte with fibroblast feeder cells (67).

Methods of Producing: Epicel is made by isolating and expanding keratinocytes obtained from a small biopsy of a patient's healthy skin. Epicel is an important treatment method for patients with severe burns due to the fact that these patients are understood to need a keratinocytebased epithelium and there isn't enough healthy skin area, which is the only other source of keratinocyte-based epithelium available for autografts for these patients.

Epicel is a cell-based product and regulated by the Center for Biologics Evaluation and Research (CBER) (68).

Application:

- Apply Epicel grafts topically to the prepared wound bed and attach Epicel in place with sutures or staples. Open the graft dishes only one time just during the grafting procedure. Do not allow the grafts to dry before application to the wound bed.

- Before treatment, obtain $0.5 \mathrm{~mL}$ of citrated or EDTA plasma and $\geq 2$ aliquots of viable, cryopreserved leukocytes blood samples for archival purposes. If a xenogeneic infectious disease is suspected, baseline patient plasma and cells may be critical to determining etiology.

- When the wound bed is fully prepared, open the first graft dish. The Epicel graft will be lying in nutrient transport medium with the growing cells facing up.

- Gently lift the graft by its backing using two forceps. A small silver orientation tag will be attached to the back of the graft.

- Apply the graft to the wound bed with the growing cells against the wound and the supporting petrolatum gauze on the outside. The silver orientation tag should be facing up. Keep the handling of the graft to a minimum. Minimize handling of the graft and do not move the graft once applied.

- Repeat the application procedure until all of the grafts are in place on the wound. Place the grafts closely, however, don't overlap.

- Once all of the grafts are applied, use a sufficient number of staples or sutures to attach the grafts to the wound bed.

- Apply a single layer of sterile nylon net over the supporting petrolatum gauze of the grafts. Staple the sterile nylon net and do not remove it for seven to 10 days.
- Apply four to five layers of absorbent gauze as a second outer covering (37).

Advantages:

- Epicel may assist in establishing a more rapid wound closure using the patient's skin (37).

- By using a patient's multi-layer skin, Epicel can provide the patient with functional tissue (37).

- Epicel was shown to lower the rate of postoperative infection by helping to facilitate early wound closure (37).

- Epicel can be used individually unlike My Skin.

- Epicel is cheaper than Epidex.

- Epicel is safer than Cryoskin.

Disadvantages:

- Sepsis (3.7\%) (69).

- Death (9\%) (69).

- The effectiveness of Epicel has not been proven in clinical studies (69).

- Multi-organ failure (3.3\%) and skin graft failure/graft complication (1.3\%) unlike Cryoskin (69).

Contraindication:

- Epicel ${ }^{\circledR}$ should not be used in patients history of anaphylaxis to vancomycin and amikacin (69).

- Epicel ${ }^{\circledR}$ should not be used in patients with sensitivities to materials of bovine or murine origin (69).

\subsection{Epidex ${ }^{\circledR}$}

Company: EpiDex, which is produced by Modex Therapeutics, Lausanne, Switzerland, had the most significant field trial in chronic wounds, especially vascular leg ulcers, which are hard to heal. The results are in line with the first and only randomized controlled trial of the German-Swiss study group (70).

EpiDex $^{\circledR}$ is an epidermis-equivalent sheet tissueengineered from autologous outer root sheath (ORS) keratinocytes, which is indicated for the treatment of chronic wounds (71).

History: Thomas Hunziker developed EpiDex and owned the patent, which was spun off and transferred to Mondex SA in 2003 (70).

Methods of Producing:EpiDex disks are attached to a silicone membrane placed on culture medium fixed with $1 \%$ agarose, after detachment from the microporous membrane. EpiDex disks are applied in the clinic within 48 hours following detachment. If required for a second application, thawed ORS cells were used 21 days after the first batch (71).

Application: A total of 50 - 200 plucked hairs per patient are cultured onto microporous membranes on the undersurface inserts carrying a feeder layer of growtharrested human dermal fibroblasts. After 14 days, ORS keratinocytes expand and reach confluence in a culture 
medium supplemented with human serum (10\%) from type AB blood. Cells are detached with trypsin and cryopreserved in liquid nitrogen. Then, on their undersurface cells are plated on microporous membranes of cell culture inserts carrying the fibroblast feeder layer. After 36 - 48 hours, the cells rose to the air-liquid interface and grown for another 14 - 16 days, with three medium changes per week. After detachment from the microporous membrane, Epidex ${ }^{\circledR}$ discs are attached to a silicone membrane, which is placed on culture medium fixed with $1 \%$ agarose in a shipment vessel (71).

Advantages:

- Repair hard-to-heal chronic wounds unlike My Skin (70).

- Suitable for small to medium sized chronic wounds (70).

- Full-thickness wound (70).

- Burn wounds.

Disadvantages:

- Infection (70).

- Dermatitis (70).

- High cost unlike Cryoskin (72).

\subsection{My Skin ${ }^{\circledR}$}

Company: Altrika Ltd, Sheffield, UK

Under the Medicines and Healthcare Products Regulatory Authority (MHRA) 'Specials' route MySkin ${ }^{\circledR}$ is recommended as part of a specialist care package for burn victims and is made available as an unlicensed medicine (73).

MySkin ${ }^{\circledR}$ is the autologous preparation of keratinocytes from patients for use on burns. MySkin ${ }^{\circledR}$ can be applied directly to the patient's burn area to promote re-epithelialization. This is a wound-healing product that uses viable cultured skin cells and is delivered as a spray. MySkin ${ }^{\circledR}$ spray can also be used for chronic wounds or ulcers (73).

History: MySkin is now produced by the Regenerys Ltd Company. It has been available in the UK since 2004 for National Health Service (NHS) patients that suffer from severe burns and chronic non-healing wounds (74).

Methods of Producing: An area of approximately 100 cm squared can be covered by The MySkin ${ }^{\circledR}$ spray, which contains two mL of keratinocytes in suspension. There can be significant variation in cell numbers available, which can be attributed to a number of factors, for example, patient age, biopsy thickness, microbial agents, and contamination (73).

Application: Patch applied (75).

Advantages:

- Partial-thickness wounds (76).

- Burn wounds (76).
- Chronic wounds (76).

- My skin is safer than Cryoskin.

Disadvantages:

- Cannot be used individually for deep wounds (77).

- My Skin shouldn't be used alone unlike Epicel.

\section{Conclusions}

To date, the clinical studies on applying stem cells in dermatology are accelerating. In the field of regenerative medicine, skin products reach the milestone very soon since their beneficial and adverse effects can be monitored easily in clinical trials. Nevertheless, our current knowledge regarding stem cells and their complex signaling pathways in their intrinsic niche still needs to be improved. Furthermore, standardized guidelines for the use of cell-based products in dermatology should be documented.

\section{Footnotes}

Conflict of Interests: There is no conflict of interests in this article.

Funding/Support: Cosmetics and Hygienic Sciences and Research Center.

\section{References}

1. Nyame TT, Chiang HA, Leavitt T, Ozambela M, Orgill DP. Tissueengineered skin substitutes. Plast Reconstr Surg. 2015;136(6):1379-88 doi: 10.1097/PRS.0000000000001748. [PubMed: 26595026].

2. Mogosanu GD, Grumezescu AM. Natural and synthetic polymers for wounds and burns dressing. Int J Pharm. 2014;463(2):127-36. doi: 10.1016/j.ijpharm.2013.12.015. [PubMed: 24368109].

3. Braddock M, Campbell CJ, Zuder D. Current therapies for wound healing: Electrical stimulation, biological therapeutics, and the potential for gene therapy. Int J Dermatol. 1999;38(11):808-17. doi: 10.1046/j.13654362.1999.00832.x. [PubMed: 10583612].

4. Crovetti G, Martinelli G, Issi M, Barone M, Guizzardi M, Campanati B, et al. Platelet gel for healing cutaneous chronic wounds. Transfus Apher Sci. 2004;30(2):145-51. doi: 10.1016/j.transci.2004.01.004. [PubMed: 15062754].

5. Parenteau NL, Rosenberg L, Hardin-Young J. The engineering of tissues using progenitor cells. In: Schatten GP, editor. Current topics in developmental biology. Philadelphia: Elsevier; 2004.

6. Li Y, Zhang J, Yue J, Gou X, Wu X. Epidermal stem cells in skin wound healing. Adv Wound Care (New Rochelle). 2017;6(9):297-307. doi:10.1089/wound.2017.0728. [PubMed: 28894637]. [PubMed Central: PMC5592843].

7. Gravitz L. Spraying on stem cells to heal burns. MIT Technol Rev. 2009.

8. Cade Hildreth (CEO) CH. Do you know the 5 types of stem cells. Bioinf. 2017

9. Yu J, Vodyanik MA, Smuga-Otto K, Antosiewicz-Bourget J, Frane JL, Tian S, et al. Induced pluripotent stem cell lines derived from human somatic cells. Science. 2007;318(5858):1917-20. doi: 10.1126/science.1151526. [PubMed: 18029452]. 
10. Hima BA, Srilatha B. Potency of various types of stem cells and their transplantation. J Stem Cell Res Therap. 2011;1(3). doi: 10.4172/21577633.1000115.

11. de Fried EP, Ross P, Zang G, Divita A, Cunniff K, Denaday F, et al. Human parthenogenetic blastocysts derived from noninseminated cryopreserved human oocytes. Fertil Steril. 2008;89(4):943-7.

12. Marquez-Curtis LA, Janowska-Wieczorek A, McGann LE, Elliott JA. Mesenchymal stromal cells derived from various tissues: Biological, clinical and cryopreservation aspects. Cryobiology. 2015;71(2):181-97. doi 10.1016/j.cryobiol.2015.07.003. [PubMed: 26186998].

13. Tabebordbar M, Zhu K, Cheng JKW, Chew WL, Widrick JJ, Yan WX, et al. In vivo gene editing in dystrophic mouse muscle and muscle stem cells. Science. 2016;351(6271):407-11. doi: 10.1126/science.aad5177. [PubMed: 26721686]. [PubMed Central: PMC4924477].

14. Andrei MC, Grosu-Bularda A, Vermesan O, Frunza A, Popescu SA, Ionita $S$, et al. Surgical treatment in acute phase of severe burns-a comprehensive approach. Modern Medicine. 2018;25(1):24-38.

15. Caulfield T, McGuire A. Athletes' use of unproven stem cell therapies: Adding to inappropriate media hype? Mol Ther. 2012;20(9):16568. doi: 10.1038/mt.2012.172. [PubMed: 22945228]. [PubMed Central: PMC3437583].

16. Kollmannsberger P, Fabry B. Linear and nonlinear rheology of living cells. Ann Rev Material Res. 2011;41(1):75-97. doi: 10.1146/annurevmatsci-062910-100351.

17. Josh P. Biomedical engineering. University of Rhode Island BME 281 First Presentation. February 23rd; Rhode Island. 2013.

18. Nathan A, Ahnood A, Cole MT, Lee S, Suzuki Y, Hiralal P, et al. Flexible electronics: The next ubiquitous platform. Proceedings of the IEEE. 2012 May 13.2012. p. 1486-517.

19. Jablonski NG. Skin: A natural history. Univ of California Press; 2008.

20. McCarthy M. Bio-engineered tissues move towards the clinic. Lancet. 1996;348(9025):466. doi: 10.1016/S0140-6736(05)64548-5. [PubMed: 8709792].

21. Brohem CA, Cardeal LB, Tiago M, Soengas MS, Barros SB, MariaEngler SS. Artificial skin in perspective: Concepts and applications Pigment Cell Melanoma Res. 2011;24(1):35-50. doi: 10.1111/j.1755148X.2010.00786.x. [PubMed: 21029393]. [PubMed Central: PMC3021617].

22. Ojeh N, Pastar I, Tomic-Canic M, Stojadinovic O. Stem cells in skin regeneration, wound healing, and their clinical applications. Int Mol Sci. 2015;16(10):25476-501. doi: 10.3390/ijms161025476. [PubMed: 26512657]. [PubMed Central: PMC4632811]

23. Mansbridge JN, Liu K, Pinney RE, Patch R, Ratcliffe A, Naughton GK. Growth factors secreted by fibroblasts: Role in healing diabetic foot ulcers. Diabetes Obes Metab. 1999;1(5):265-79. doi: 10.1046/j.14631326.1999.00032.x. [PubMed: 11225638].

24. Meikle ST. Silver-doped hydrogels for wound dressings. Wound Healing Biomaterials. Elsevier; 2016. p. 335-51.

25. Weller C. 4 - Interactive dressings and their role in moist wound management. In: Rajendran S, editor. Advanced textiles for wound care. Woodhead Publishing; 2009. p. 97-113. doi: 10.1533/9781845696306.1.97.

26. Smith J. Book review: Fundamentals of hand therapy: Clinical reasoning and treatment guidelines for common diagnoses of the upper extremity. Canadian J Occupat Therap. 2015;82(2):128. doi $10.1177 / 0008417415570472$.

27. Natesan S, Zamora DO, Wrice NL, Baer DG, Christy RJ. Bilayer hydrogel with autologous stem cells derived from debrided human burn skin for improved skin regeneration. J Burn Care Res. 2013;34(1):18-30. doi 10.1097/BCR.ob013e3182642c0e. [PubMed: 23292571].

28. Sudhakar CK, Upadhyay N, Jain A, Verma A, Narayana Charyulu R, Jain S. Chapter 5 - hydrogels-promising candidates for tissue engineering. In: Thomas S, Grohens Y, Ninan N, editors. Nanotechnology applications for tissue engineering. William Andrew; 2015. p. 77-94. doi 10.1016/b978-0-323-32889-0.00005-4.

29. Felgueiras HP, Amorim MTP. Functionalization of electrospun poly- meric wound dressings with antimicrobial peptides. Colloids and Surfaces B: Biointerfaces. 2017;156:133-48.

30. Chen S, Shi J, Zhang M, Chen Y, Wang X, Zhang L, et al. Mesenchymal stem cell-laden anti-inflammatory hydrogel enhances diabetic wound healing. Sci Rep. 2015;5:18104. doi:10.1038/srep18104. [PubMed: 26643550]. [PubMed Central: PMC4672289].

31. Erovic BM, Lercher P. Manual of head and neck reconstruction using regional and free flaps. Springer; 2014.

32. Rheinwald JG, Green H. Serial cultivation of strains of human epidermal keratinocytes: The formation of keratinizing colonies from single cells. Cell. 1975;6(3):331-43. doi: 10.1016/S0092-8674(75)80001-8. [PubMed: 1052771].

33. Gallico GG, O'Connor NE, Compton CC, Kehinde O, Green H. Permanent coverage of large burn wounds with autologous cultured human epithelium. N Engl J Med. 1984;311(7):448-51. doi: 10.1056/NEJM198408163110706. [PubMed: 6379456].

34. Ter Horst B, Chouhan G, Moiemen NS, Grover LM. Advances in ker atinocyte delivery in burn wound care. Adv Drug Deliv Rev. 2018;123:1832. doi: 10.1016/j.addr.2017.06.012. [PubMed: 28668483]. [PubMed Central: PMC5764224].

35. Fredriksson C, Kratz G, Huss F. Transplantation of cultured human keratinocytes in single cell suspension: A comparative in vitro study of different application techniques. Burns. 2008;34(2):212-9. doi: 10.1016/j.burns.2007.03.008.

36. Pomahac B, Svensjo T, Yao F, Brown H, Eriksson E. Tissue engineering of skin. Crit Rev Oral Biol Med. 1998;9(3):333-44. doi: 10.1177/10454411980090030601. [PubMed: 9715370].

37. Elliott M, Vandervord J. Initial experience with cultured epithelial autografts in massively burnt patients. ANZJ Surg. 2002;72(12):893-5. doi: 10.1046/j.1445-2197.2002.02591.x. [PubMed: 12485229].

38. Naughton G, Mansbridge J, Gentzkow G. A metabolically active human dermal replacement for the treatment of diabetic foot ulcers. Artif Organs. 1997;21(11):1203-10. doi: 10.1111/j.1525-1594.1997.tb00476.x. [PubMed: 9384327].

39. Omar AA, Mavor AI, Jones AM, Homer-Vanniasinkam S. Treatment of venous leg ulcers with Dermagraft. Eur J Vasc Endovasc Surg. 2004;27(6):666-72. doi: 10.1016/j.ejvs.2004.03.001. [PubMed: 15121121].

40. Dodson BP, Levine AD. Challenges in the translation and commercialization of cell therapies. BMC Biotechnol. 2015;15:70. doi: 10.1186/s12896-015-0190-4. [PubMed: 26250902]. [PubMed Central: PMC4528687].

41. Purdue GF, Hunt JL, Still JM, Law EJ, Herndon DN, Goldfarb IW, et al. A multicenter clinical trial of a biosynthetic skin replacement, dermagraft-tc, compared with cryopreserved human cadaver skin for temporary coverage of excised burn wounds. J Burn Care Rehabilit. 1997;18(1):52-7. doi: 10.1097/00004630-199701000-00009.

42. Hansbrough JF, Mozingo DW, Kealey GP, Davis M, Gidner A, Gentzkow GD. Clinical trials of a biosynthetic temporary skin replacement, Dermagraft-Transitional Covering, compared with cryopreserved human cadaver skin for temporary coverage of excised burn wounds. J Burn Care Rehabil. 1997;18(1 Pt 1):43-51. doi: 10.1097/00004630199701000-00008. [PubMed: 9063787].

43. Bello YM, Falabella AF, Eaglstein WH. Tissue-engineered skin. Current status in wound healing. Am J Clin Dermatol. 2001;2(5):305-13. doi: 10.2165/00128071-200102050-00005. [PubMed: 11721649].

44. Kumar RJ, Kimble RM, Boots R, Pegg SP. Treatment of partial-thickness burns: A prospective, randomized trial using Transcyte. ANZ J Surg. 2004;74(8):622-6. doi: 10.1111/j.1445-1433.2004.03106.x. [PubMed: 15315558].

45. Mekkes JR, Loots MA, Van Der Wal AC, Bos JD. Causes, investigation and treatment of leg ulceration. Br J Dermatol. 2003;148(3):388-401. doi: 10.1046/j.1365-2133.2003.05222.x. [PubMed: 12653729].

46. Kemp P. History of regenerative medicine: looking backwards to move forwards. Regen Med. 2006;1(5):653-69. doi: 10.2217/17460751.1.5.653. [PubMed: 17465733] 
47. Vyas KS, Vasconez HC. Wound healing: Biologics, skin substitutes, biomembranes and scaffolds. Healthcare (Basel). 2014;2(3):356-400. doi: 10.3390/healthcare2030356. [PubMed: 27429283]. [PubMed Central: PMC4934597].

48. Placencio K, Jefferson TF, Teran M, Fenn M. Artificial skin and wound dressings. In: Hench LL, Fenn MB, Jones JR, editors. New materials and technologies for healthcare. London: World Scientific; 2012. p. 201-25.

49. Wainwright DJ. Use of an acellular allograft dermal matrix (AlloDerm) in the management of full-thickness burns. Burns. 1995;21(4):243-8. doi: 10.1016/0305-4179(95)93866-I. [PubMed: 7662122].

50. Shorr N, Goldberg RA, Hoenig J, Perry JD, Shorr JK. More information on Alloderm. Ophthalmic Plast Reconstr Surg. 2001;17(2):153-4. doi: 10.1097/00002341-200103000-00019. [PubMed: 11281594].

51. Schwade N. Implants, soft tissue, Alloderm. [cited 2007]. Available from: http://www.emedicine.com/ent/topic377.htm.

52. Sclafani AP, Romo T, Jacono AA, McCormick S, Cocker R, Parker A Evaluation of acellular dermal graft in sheet (AlloDerm) and injectable (micronized AlloDerm) forms for soft tissue augmentation. Clinical observations and histological analysis. Arch Facial Plast Surg. 2000;2(2):130-6. doi: 10.1001/archfaci.2.2.130. [PubMed:10925439].

53. Ghetti M, Bondioli E, Purpura V, Cenacchi G, Ruscelli P, Melandri D. Decellularized human dermal matrix produced by a skin bank: A new treatment for abdominal wall defects. Ann Ital Chir. 2017;5:443-8. [PubMed: 28874630].

54. Kimmel H, Gittleman H. Retrospective observational analysis of the use of an architecturally unique dermal regeneration template (Derma Pure(R)) for the treatment of hard-to-heal wounds. Int Wound J. 2017;14(4):666-72. doi: 10.1111/iwj.12667. [PubMed: 27619480].

55. Son JH, Bafus B, Khandelwal A, Chepla KJ. Reconstruction of a circumferential upper extremity soft tissue defect with a dermal regeneration template and skin grafting. Techniq hand upper extremity surg. 2018;22(1):31-3.

56. Heimbach DM, Warden GD, Luterman A, Jordan MH, Ozobia N, Ryan $\mathrm{CM}$, et al. Multicenter postapproval clinical trial of Integra ${ }^{\circ}$ dermal regeneration template for burn treatment. J Burn Care Rehabilit. 2003;24(1):42-8. doi: 10.1097/00004630-200301000-00009.

57. Heitland A, Piatkowski A, Noah EM, Pallua N. Update on the use of collagen/glycosaminoglycate skin substitute-six years of experiences with artificial skin in 15 German burn centers. Burns. 2004;30(5):471-5. doi:10.1016/j.burns.2004.01.010. [PubMed: 15225914].

58. Peck MD, Kessler M, Meyer AA, Bonham Morris PA. A trial of the effectiveness of artificial dermis in the treatment of patients with burns greater than $45 \%$ total body surface area. J Trauma. 2002;52(5):971-8. doi: 10.1097/00005373-200205000-00024. [PubMed: 11988667].

59. Billmeyer FW. Textbook of polymer science. Food and Agriculture Organization of the United Nations; 1971

60. Lehr VT, Lulic-Botica M, Lindblad WJ, Kazzi NJ, Aranda JV. Management of infiltration injury in neonates using duoderm hydroactive gel. Am J Perinatol. 2004;21(7):409-14. doi: 10.1055/s-2004-835309. [PubMed: 15476132].

61. Hartford CE, Kealey GP. Care of outpatient burns. In: Herndon DN, ed- itor. Total burn care. 4th ed. Philadelphia, PA: Saunders; 2012.

62. May Leveriza O, Phillips. T. J . Dressings and postoperative carea. In: Dockery GD, Crawford ME, editors. Lower extremity soft tissue cutaneous plastic surgery. 2nd ed. Elsevier; 2012. p. 471-88.

63. Hess CT. Skin and wound care. 6th ed. Philadelphia: Lippincott Williams \& Wilkins; 2008.

64. Solosko T, Ryan B, Feuersanger RA, Hugh SC. Improved biomedical electrode for extended patient wear featuring a tap, or snap, which is isolated from the retentional seal. United States patent application US 12/161,701. 2010.

65. Rippon M, White R, Davies P. Skin adhesives and their role in wound dressings. Wounds UK. 2007;3(4):76.

66. Andreassi L. History of keratinocyte cultivation. Burns. 1992;18 Suppl 1:S2-4. doi: 10.1016/0305-4179(92)90102-Z. [PubMed: 1554420].

67. Chu GY, Chen YF, Chen HY, Chan MH, Gau CS, Weng SM. Stem cell therapy on skin: Mechanisms, recent advances and drug reviewing issues. J Food Drug Anal. 2018;26(1):14-20. doi: 10.1016/j.jfda.2017.10.004 [PubMed: 29389549].

68. Morgado PI, Aguiar-Ricardo A, Correia IJ. Asymmetric membranes as ideal wound dressings: An overview on production methods, structure, properties and performance relationship. J Membrane Sci. 2015;490:139-51. doi:10.1016/j.memsci.2015.04.064.

69. EpiCel ${ }^{\mathrm{TM}}$. Cultured keratinocytes for burns. 2018, [cited 20 Aug 2018] Available from: https://discovery.lifemapsc.com/regenerativemedicine/cell-therapy-applications/epidermis-skin-epicelcultured-keratinocytes-for-burns.

70. Ortega-Zilic N, Hunziker T, Lauchli S, Mayer DO, Huber C, Baumann Conzett K, et al. EpiDex(R) Swiss field trial 2004-2008. Dermatology. 2010;221(4):365-72. doi: 10.1159/000321333. [PubMed: 21071921].

71. Msika P, Baudouin C. Method for identifying molecular markers of children's skin. Lab Expansci. 2015.

72. Ferreira MC, Paggiaro AO, Isaac C, Teixeira Neto N, Santos G. [Skin substitutes: current concepts and a new classification system]. Revista Brasileira de Cirurgia Plástica. 2011;26(4):696-702. Portuguese. doi: 10.1590/s1983-51752011000400028.

73. Pearson S. Cell therapy building on momentum: Success of dendreon's provenge illuminates possibilities in this fast-growing field Genetic Eng Biotechnol New. 2011;31(9):46-7. doi:10.1089/gen.31.9.22.

74. MacNeil S. Developing cell carriers for delivering cells from the laboratory to the clinic - clinical and commercial experiences. USES 2014 - The University of Sheffield Engineering Symposium. 24 June 2014; Sheffield. The Octagon Centre, University of Sheffield; 2015.

75. Kim JJ, Evans GR. Applications of biomaterials in plastic surgery. Clin Plast Surg. 2012;39(4):359-76. doi: 10.1016/j.cps.2012.07.007. [PubMed: 23036287].

76. Damanhuri MH, Boyle JM, Enoch S. Technology update. Manag. 2005;52:197-203.

77. Shevchenko RV, James SL, James SE. A review of tissue-engineered skin bioconstructs available for skin reconstruction. J $R$ Soc Interface. 2010;7(43):229-58. doi: 10.1098/rsif.2009.0403. [PubMed: 19864266]. [PubMed Central: PMC2842616]. 